remainder are representative examples of the ordinary farmers of Great Britain. The accounts, which cover a wide range of current practice in dairy farming, are resdable and enlightening; and they are illustrated by a useful selection of photographs.

The other half of the book purports to deal with the scientific principles of dairy farming; but this section is singularly rambling for a scientific work and the principles are diluted with platitudes. The diction is sometimes puzzling ; for example, when the author states "A skilful breeder will frequently raise a herd of animals that are very similar to the eye". Many of the definitions are inept, and a new agricultural student might be misled by reading that a starchy food is one that contains a small amount of protein.

The general conception of the book and part of the contents are excellent; the style of the remainder will have a limited appeal, but in any case should be read in conjunction with more authoritative works.

S. B.

\section{Birds of the Southwest Pacific}

A Field Guide to the Birds of the Area between Samoa, New Caledonia and Micronesia. By Ernst Mayr. Pp. $\mathrm{xx}+316+3$ plates. (New York: The Macmillan Company ; London : Macmillan and Co., Ltd., 1945.) 18s. net.

1 HE south-west Pacific, that is, the area between Samoa, New Caledonia and Micronesia, is a rich ornithological field, many interesting and varied species of birds being found in it. This little book is a field guide to them, its author, Dr. Mayr, having worked for many years on Pacific ornithology. In his introduction he points out that the difficulties and the interest of the task are enhanced by the many separate archipelagos involved, each with its distinct bird fauna, though certain species are common to many if not all the archipelagos. He therefore divides his book into a general section and a geographical section, dealing with the seabirds, shorebirds, and land and freshwater birds of the area in the first part, and taking the faunas of the different groups of islands separately in the latter section. The coloured plates and the black-and-white sketches are helpful and enhance the value of a very useful book. Frances PrTt

\section{Archéologie du Pacifique-Nord}

Matériaux pour l'étude des relations entre les peuples riverains d'Asie et d'Amérique. Par Dr. André Leroi-Gourhan. (Université de Paris : Travaux et mémoires de l'Institut d'ethnologie, Tome 47.) Pp. xviii +542. (Paris: Institut d'Ethnologie, 1946.) 700 francs.

$\mathrm{T}$ WIIS volume deals with the archæology of the North Pacific in two parts. The first deals with the area generally and with the inhabitants of different regions severally-Japan, the Ainu, Kamschatka, the Eskimo of four different regions, and the Aleutian Islands and British Columbia. In the second part the author takes some fifteen or sixteen implements of common use and widespread occurrence, analyses the various types, and shows their distribution on sketch maps. The Eskimo in particular afford a remarkable instance of an extremely wide distribution of material types, due in part to their possession of a common language and culture, in part to the extremely small and scattered population using the artefacts in question. Life in the North Pacific is necessarily dependent on a highly specialized material culture in which the nature of every tool is strictly determined by the physical environment.

The author comes to the conclusion that it is possible in a sense to speak of a North Pacific civiliza. tion, but he rejects any suggestion of a common focus of culture or of the importation of a formed culture from outside the area dealt with. He points out that the remotest period covered by archæological finds cannot be shown to be more than two thousand years ago ; that during all that period the population of the area concerned has possessed a comparatively stable physical type; and that the distribution of various types of artefact indicates lines of communication, not of migration. He infers, in consequence, the general danger in archæology of build. ing up theories of migration on the data of typological distribution. Human movement is much less frequent and very much slower than the movements of material culture.

The volume contains a good bibliography of wide range in date and language, a rather poor index, forty-three good maps mostly of distribution, and 1,148 text figures. The work is an important one not only as a study of North Pacific cultures, but also in reference to archæological method in general.

J. H. HuTTON

\section{The Navaho}

By Clyde Kluckhohn and Dorothea Leighton. Pp. $\mathrm{xx}+258+20$ plates. (Cambridge, Mass. : Harvard University Press; London: Oxford University Press, 1946.) 25s, net.

7 HE recent increase in the Navajo population and the reduction in fertility of the land in their reservation, consequent upon soil erosion, has con. fronted them with a serious material problem. Their contact with the civilization of the white man has aggravated this and introduced an equally grave spiritual problem. The Indian Field Service is doing its best to help them; but the policy of moving the administrators from tribe to tribe on promotion prevents them from really getting to know any of the Indians.

This book is one of a series of tribal monographs published on behalf of an Indian Education Research Project sponsored by the University of Chicago and the U.S. Office of Indian Affairs. It deals primarily with Navajo life at the present time, and is designed chiefly to instruct the administrators and teachers who work among these people. The deep concern of the authors for the welfare of the Navajos is shown by it and other books which they have written, and it is a useful, though necessarily limited, study of culture contact, based on intimate knowledge. How far their audience lags behind them is shown by the fact that they find it necessary to insist, at some length, upon such elementary matters as the importance of acquiring at least a smattering of the Navajo language.

That the Navajo word for themselves can be trans. lated 'people' or 'the people' is by no means an isolated phenomenon, so the frequent reference to them as The People, which recurs throughout the book, is an irritating mannerism. The production of the book is up to the high standard which we expect of the Harvard University Press, and it is illustrated by some admirable photographs.

G. H. S. Bushnell 